\title{
PREVALENCE AND MANAGEMENT OF REFRACTORY MERALGIA PARESTHETICA IN LUMBAR SPINE SURGERY: 5 YEARS OF EXPERIENCE
}

\author{
PREVALÊNCIA E MANEJO DA MERALGIA PARESTÉSICA REFRATÁRIA EM CIRURGIA DE \\ COLUNA LOMBAR: EXPERIENCIA DE CINCO ANOS
}

PREVALENCIA Y MANEJO DE LA MERALGIA PARESTÉSICA REFRACTARIA EN CIRUGÍA DE COLUMNA LUMBAR: EXPERIENCIA DE 5 AÑOS

\author{
Jose Augusto Malheiros ${ }^{1,2,3}$, Celia Maria de Oliveira ${ }^{4}$, Aluizio Augusto Arantes Junior ${ }^{1,5,6}$, Jonas Soares Silva Santos ${ }^{3}$, Sebastião Natanael Silva Gusmão $1,6,7$ \\ 1. Universidade Federal de Minas Gerais (UFMG), Hospital das Clínicas, Belo Horizonte, MG, Brazil. \\ 2. Hospital Felicio Rocho, Belo Horizonte, MG, Brazil. \\ 3. Hospital Luxemburgo, Belo Horizonte, MG, Brazil. \\ 4. Universidade Federal de Minas Gerais (UFMG), Faculdade de Enfermagem, Belo Horizonte, MG, Brazil. \\ 5. Hospital Madre Teresa, Belo Horizonte, MG. Brazil. \\ 6. Universidade Federal de Minas Gerais (UFMG), Faculdade de Medicina, Department of Surgery, Belo Horizonte, MG, Brazil. \\ 7. Hospital Universitário de Diamantina, Diamantina, MG, Brazil.
}

\begin{abstract}
Objective: The objective of our study was to report 5 years of experience in the recognition and management of refractory meralgia paresthetica (MP) in patients who had undergone posterior approach lumbar surgery. Methods: Patients who were submitted to procedures in the lumbar spine from January 2010 to January 2015 in three different hospital centers in Belo Horizonte/MG were selected for an evaluation of the postoperative development of MP. A prospective observational comparative case series study. Level of evidence III. Evaluation of the following parameters: type of support for the patient, surgical time, body mass index. Results: 367 posterior approach lumbar spine surgeries for degenerative pathologies of the lumbar spine were performed. MP was observed in 81 patients (22\%). In 65 of those patients (80\%), there was complete resolution of the symptoms with conservative management (local measures and medications for neuropathic pain) in less than two months. Twelve patients improved with a corticosteroid depot injection in the inguinal ligament and four patients required a surgical procedure in the third month. Pneumatic support was the least involved in the development of MP, as well as surgical time $<1 \mathrm{~h}$ and body mass index <25. Conclusion: Refractory MP may occur in patients submitted to posterior approach lumbar spine surgeries. Management includes local measures, medications for neuropathic pain, and corticosteroid injection in the inguinal ligament. Decompression surgery is reserved for rare refractory cases. Level of evidence III; Prospective observational study with comparative case series.
\end{abstract}

Keywords: Meralgia Paresthetica; Lateral Femoral Cutaneous Nerve Entrapment; Lumbosacral Region; Low Back Pain; Surgery.

\section{RESUMO}

Objetivo: O objetivo do presente estudo consiste em relatar a experiência de cinco anos no reconhecimento e manejo da meralgia parestésica (MP) refratária em pacientes submetidos a cirurgias lombares por via posterior. Métodos: Pacientes submetidos a procedimentos na coluna lombar, no período de janeiro de 2010 a janeiro de 2015, em três diferentes centros hospitalares de Belo Horizonte/MG, foram selecionados para avaliação do desenvolvimento da MP pós-operatória. Estudo prospectivo observacional com série de casos comparativos. Nível III de evidência. Avaliação dos seguintes parâmetros: tipo de suporte para o paciente, tempo de cirurgia, índice de massa corporal. Resultados: Foram feitas 367 cirurgias por via posterior da coluna lombar para patologias degenerativas da coluna lombar. A MP foi observada em 81 pacientes (22\%). Em 65 pacientes (80\%), houve resolução completa dos sintomas com manejo conservador (medidas locais e medicamentos para dor neuropática) em menos de dois meses. Doze pacientes melhoraram através de infiltração com corticoide de depósito e anestésico no local no ligamento inguinal e, em quatro pacientes houve necessidade de procedimento cirúrgico no terceiro mês. O suporte pneumático foi o menos envolvido no desenvolvimento da MP, assim como o tempo cirúrgico <1h e índice de massa corporal <25. Conclusão: A MP refratária pode ocorrer em pacientes submetidos a cirurgias na coluna lombar por via posterior. O manejo inclui medidas locais, medicamentos para dor neuropática e infiltração com corticoide no ligamento inguinal. A cirurgia descompressiva está reservada para os raros casos refratários. Nível de evidência III; Estudo prospectivo observacional com série de casos comparativos.

Descritores: Meralgia Parestésica; Compressão de Nervo Cutâneo Lateral da Coxa; Região Lombossacral; Lombalgia; Cirurgia.

\section{RESUMEN}

Objetivo: El objetivo del presente estudio consiste en relatar la experiencia de 5 años en el reconocimiento y manejo de la meralgia parestésica (MP) refractaria en pacientes sometidos a cirugías lumbares por vía posterior. Métodos: Pacientes sometidos a procedimientos en la columna lumbar, en el período de enero de 2010 a enero de 2015, en tres diferentes centros hospitalarios de Belo Horizonte/MG, fueron seleccionados para evaluación del desarrollo de la MP postoperatoria. Estudio prospectivo obsenacional con serie de casos comparativos. 
Nivel III de evidencia. Evaluación de los siguientes parámetros: tipo de soporte para el paciente, tiempo de cirugía, índice de masa corporal. Resultados: Se realizaron 367 cirugías por vía posterior de la columna lumbar para patologías degenerativas de la columna lumbar. La MP fue observada en 81 pacientes (22\%). En 65 pacientes (80\%) hubo resolución completa de los síntomas con manejo conservador (medidas locales y medicamentos para el dolor neuropático) en menos de 2 meses. Doce pacientes mejoraron a través de infiltración de corticoide de depósito y anestésico en el local en el ligamento inguinal y, en cuatro pacientes, hubo necesidad de procedimiento quirúrgico en el tercer mes. El soporte neumático fue el menos involucrado en el desarrollo de la MP, así como el tiempo quirúrgico <1h e índice de masa corporal <25. Conclusión: La MP refractaria puede ocurrir en pacientes sometidos a cirugías en la columna lumbar por vía posterior. El manejo incluye medidas locales, medicamentos para el dolor neuropático e infiltración con corticoide en el ligamento inguinal. La cirugía descompresiva está resenada para los raros casos refractarios. Nivel de evidencia III; Estudio prospectivo observacional con serie de casos comparativos.

Descriptores: Meralgía Parestésica; Nervio Cutáneo Lateral Femoral; Región Lumbosacra; Dolor de la Región Lumbar; Cirugía.

\section{INTRODUCTION}

Meralgia paresthetica is the compressive mononeuropathy of the lateral cutaneous nerve of the thigh (or lateral cutaneous femoral nerve) and can cause discomfort and neuropathic pain in the anterolateral region of the thigh. ${ }^{1}$ It is estimated that the incidence of meralgia paresthetica following lumbar spine surgery in the prone position is approximately $20 \%{ }^{2,3}$ Despite being a relatively common complication, there are few reports in the international literature and none in the Latin American, ${ }^{3-5}$ as well as an absence of focus on the management of refractory cases.

Objective: To report the experience with and management of refractory meralgia paresthetica in patients submitted to posterior approach lumbar spine surgery.

\section{METHODS}

Hospital das Clinicas - UFMG - Faculdade de Medicina: Institutional review board protocol number, CAAE - 8295381860000 5149 - Treatment of postoperative pain in arthrodesis patients.

Patients with degenerative lumbar spine disease who were going to be submitted to some posterior approach procedure were selected after filling out the Informed Consent Form and approval of the study by the Institutional Review Board. Oncological surgeries, spinal cord surgeries, spinal cord trauma surgeries, and surgeries of the upper lumbar levels L1, L2, and L3 were excluded.

A diagnosis of meralgia paresthetica was based on clinical evaluation and should meet the two criteria: positive Tinel's sign in the inguinal ligament and neuropathic pain on the anterolateral surface of the thigh.

Period: January 2010 to January 2015. Three different hospital centers: Hospital das Clinicas - UFMG; Hospital Luxemburgo; Hospital Felicio Rocho. Belo Horizonte/MG. Brazil.

A prospective, observational study was conducted in these three centers with the following evaluation criteria: type of patient support, surgical time, and body mass index.

Success of the treatment was confirmed by a score of less than 4, mild pain, on the Verbal Numeric Scale (VNS), and by the disappearance of the Tinel's sign on the inguinal ligament and of the burning on the lateral surface of the thigh.

The times of appearance and disappearance of the symptoms were noted. Refractory cases were defined as the lack of improvement - Verbal Numeric Scale for Pain (VNS) > 5 and persistence of symptoms beyond two months, despite medication and local measures.

Treatments with medication, depot injection of corticosteroids, and surgical decompression of the cutaneous femoral nerve were evaluated.

\section{RESULTS}

There was a total of 367 posterior approach lumbar spinal surgeries for degenerative lumbar spinal pathologies. Oncological surgeries, intra-spinal surgeries, trauma surgeries, and surgeries of upper lumbar levels L1, L2, and L3, which can mimic meralgia paresthetica through the manipulation of the nerve roots involved at these levels, were excluded.

Meralgia paresthetica was observed in 81 patients (22\%), 77 (95\%) of whom were diagnosed during the first postoperative week; in four patients (5\%) it occurred during the second week.
Sixty-five patients (80\%) had full recovery of symptoms in under two months with conservative management, that is, local measures and medications for neuropathic pain. Meralgia refractory to drug treatment was observed in 16 patients, 12 of whom improved with depot corticosteroid and anesthetic injections at the location where there was a positive Tinel's sign in the inguinal ligament, and the condition resolved in six months. In four patients, a surgical procedure was necessary in the third month with cutaneous femoral nerve decompression under local anesthesia and sedation. One patient required a neurectomy in the sixth postoperative month.

Regarding the operating table supports used, 48 surgeries were performed using the Wilson Bridge, 162 surgeries were performed using cloth cushions, and 157 were performed using automobile inner tubes as supports. (Table 1) The other variables analyzed in this study, such as surgical time and body mass index, are shown in Tables 2 and 3, respectively.

Table 1. Table support and Meralgia Paresthetica.

\begin{tabular}{c|c|c|c}
\hline Table support & Cloth cushions & Wilson bridge & Inner tube \\
\hline Yes & $45(27 \%)$ & $20(41 \%)$ & $16(10 \%)$ \\
\hline No & 117 & 28 & 141 \\
\hline Total & 162 & 48 & 157 \\
\hline \multicolumn{4}{|r|}{}
\end{tabular}

Table 2. Surgical time and Meralgia Paresthetica.

\begin{tabular}{c|c|c|c}
\hline Surgical time & $<\mathbf{1}$ Hour & $\mathbf{1 - 3}$ Hours & $>\mathbf{3}$ Hours \\
\hline yes & $2(4 \%)$ & $35(16 \%)$ & $44(42 \%)$ \\
\hline No & 48 & 179 & 59 \\
\hline Total & 50 & 214 & 103 \\
\hline
\end{tabular}

Table 3. BMI and Meralgia Paresthetica.

\begin{tabular}{c|c|c|c}
\hline Body mass index & $\mathbf{2 5}$ & $\mathbf{2 5 - 3 0}$ & $\mathbf{3 0}$ \\
\hline Yes & $4(8 \%)$ & $66(21 \%)$ & $11(64 \%)$ \\
\hline No & 44 & 236 & 6 \\
\hline Total & 48 & 302 & 17 \\
\hline
\end{tabular}

\section{DISCUSSION}

Meralgia paresthetica (MP) is a relatively common compressive mononeuropathy of the lower limbs, first described by Bernardt-Roth in $1878 .{ }^{6}$ The first cutaneous femoral nerve decompression surgery of the thigh was performed by Harvey Cushing in $1900 .{ }^{6}$ The main risk factors for this syndrome are obesity, tight clothing, surgeries in which grafts are taken from the iliac crest, pregnancy, and prolonged surgeries performed with the patient in the prone position., 6

Posterior approach lumbar spine surgeries, even without iliac crest graft removal, have been reported to be predisposed to this syndrome $^{3,5,6}$. (Figure 1) In this study, the prevalence of MP was $22 \%$, which is consistent with the case series described in the literature.

This study includes aspects that have not yet been addressed in the literature, such as the type of support used and how to proceed in refractory cases that have not improved after two months of treatment.

In most cases, meralgia paresthetica is a common benign condition 
with complete resolution after a few weeks. In our study, we adopted conservative treatment with medications and local measures, that is, massage, compresses, and loose clothing for up to two months following surgery. The two-month timeframe was based on the work of Yang et al., in which remission within two months was reported in all cases.

Table 4 shows the progression of the MP treatment. It begins with local measures and medications and continues with a corticosteroid injection, eventually leading to surgery in refractory cases.

In cases where there was no improvement after the first two months, we opted for an injection of $10 \mathrm{ml}$ of depot corticosteroids (methylprednisolone acetate) associated with a local anesthetic (ropivacaine 1\%) at the point of pain on percussion (positive Tinel's sign) in the inguinal ligament. (Figure 2) This procedure aimed to confirm both the diagnosis ${ }^{6}$ and the therapy.

Following the injection of depot corticosteroid with anesthetic solution, we observed improvement in $75 \%$ of the cases (12 of the 16 refractory patients). This procedure has not yet been described in the specific management of MP in patients submitted to lumbar spine surgery and we believe that it can be a valid tool in the management of refractory cases or in those in which there is doubt about postoperative lumbar radiculopathy. One month after said procedure, the pain profile recurred in four patients and we decided to perform cutaneous femoral nerve decompression surgery. (Figure 3) In one of these four patients, we performed a neurectomy of the cutaneous femoral nerve two months following decompression surgery. All the patients were followed-up for more than one year.

Another aspect analyzed that has not been emphasized in the literature is the type of support used for the prone position. We observed that pneumatic support (automobile tire inner tube) was

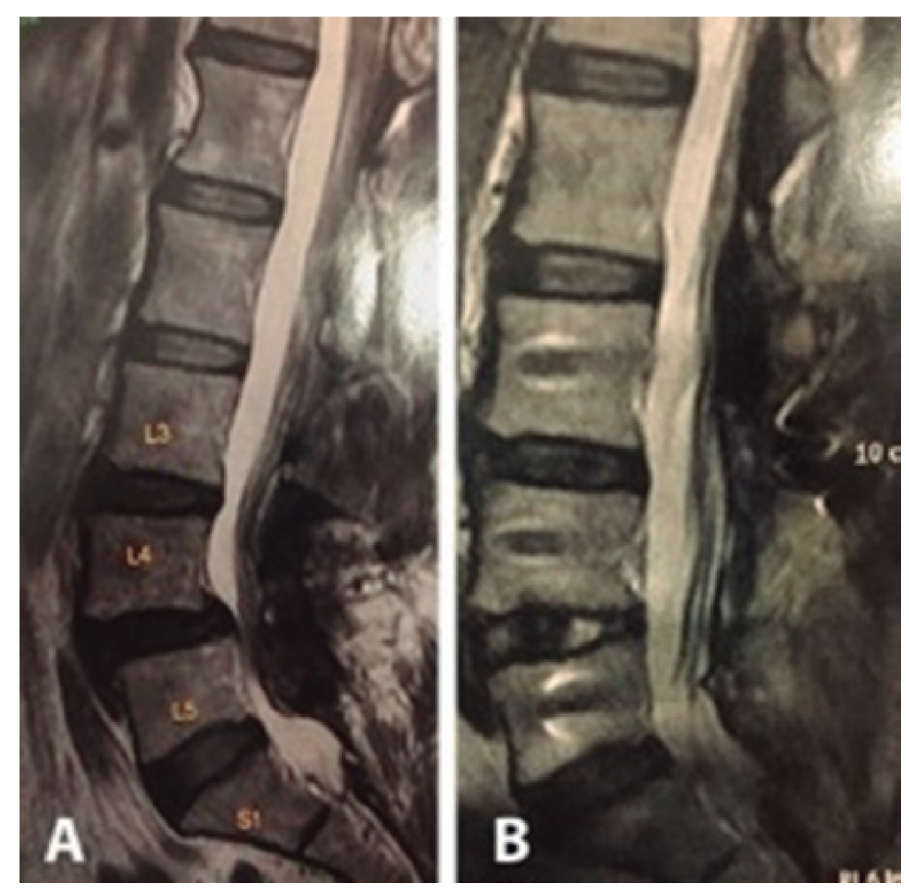

Figure 1. One of the cases that evolved with refractory meralgia paresthetica after L3-L4-L5 lumbar spine arthrodesis with L4-L5 TLIF. A - preoperative magnetic resonance examination. $\mathrm{B}$ - postoperative control examination.

Table 4. Progression of Treatment of Postsurgical Meralgia Paresthetica.

\begin{tabular}{c|c|c}
\hline $\begin{array}{c}\text { 1st) Drug treatment } \\
\text { with local measures }\end{array}$ & $\begin{array}{c}\text { 2nd) Depot } \\
\text { corticosteroid and } \\
\text { anesthetic injection }\end{array}$ & 3rd) Surgical treatment \\
\hline Gabapentin & $\begin{array}{c}\text { Methylprednisolone } \\
\text { acetate + Ropivacaine } \\
1 \%\end{array}$ & $\begin{array}{c}\text { Decompression / } \\
\text { Neurolysis }\end{array}$ \\
\hline Pregabalin/Valproate & & Neurectomy \\
\hline
\end{tabular}

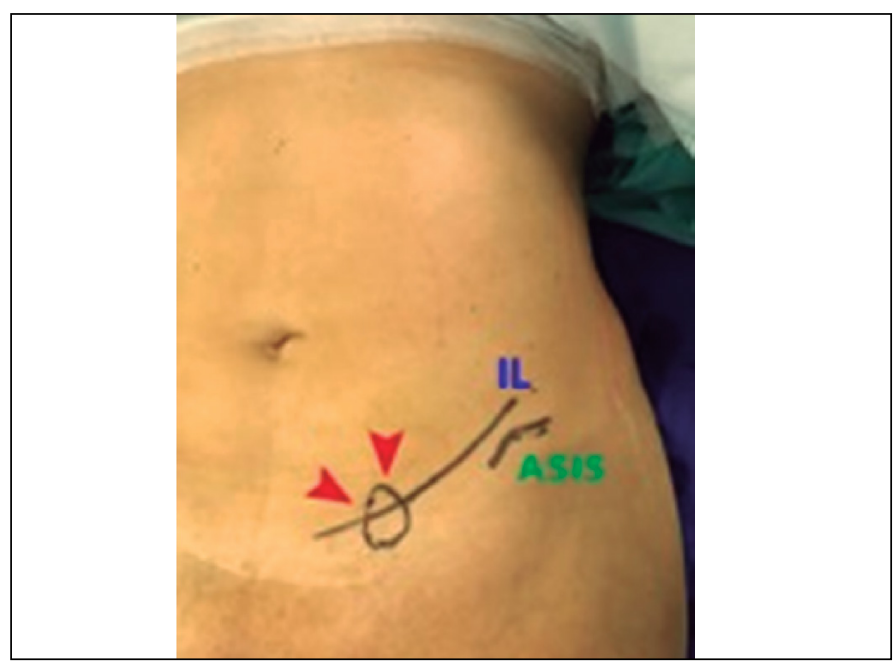

Figure 2. Red arrows indicate the Tinel's sign for performing the corticosteroid injection. IL = inguinal ligament. ASIS = anterior superior iliac spine.
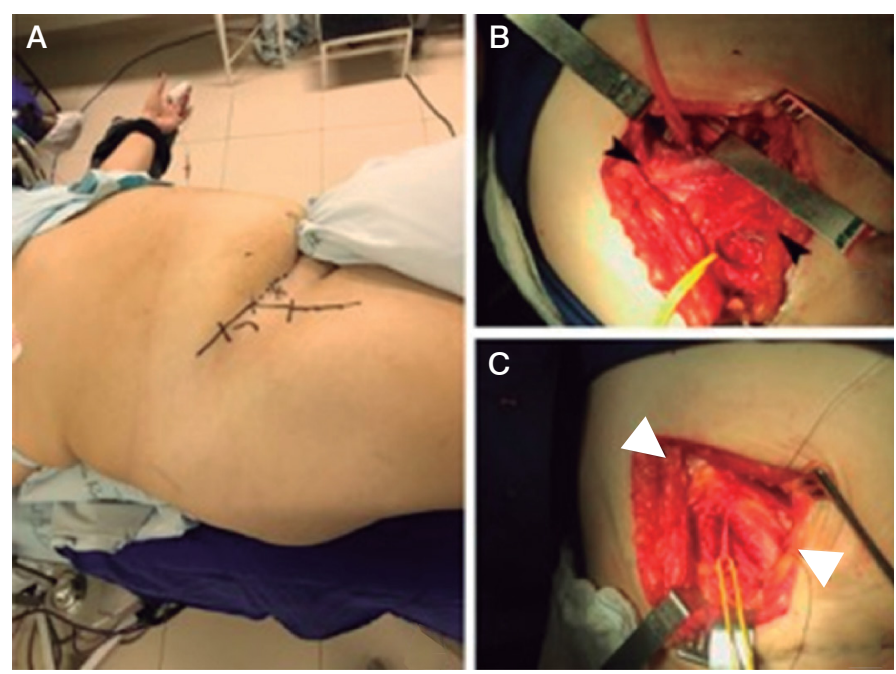

Figure 3. Planning for the incision following the inguinal ligament. B. Retroperitoneal exposure in the thigh of the femoral cutaneous nerve. C. Result after nerve decompression. Arrows delimit the inguinal ligament.

the type of support least associated with the appearance of MP, followed by cloth cushions and the Wilson Bridge.

The risk factors observed in the study associate the pathogenesis of MP with the point of greatest pressure. This finding indicates that the use of more rigid supports is a probable compression risk factor in the genesis of postoperative lumbar MP.

The main limitations of this study are its observational character and the absence of a control group for the treatment of refractory cases. Therefore, we cannot state whether treatment with inguinal ligament injection or surgical treatment is better than simple observation and adequate drug treatment.

\section{CONCLUSION}

Refractory MP may occur in patients who underwent posterior approach lumbar spine surgery. Its management includes local measures, medication for neuropathic pain, and corticosteroid injections into the inguinal ligament. In refractory cases, decompression surgery or retroperitoneal neurectomy may be performed.

All authors declare no potential conflict of interest related to this article. 
CONTRIBUTION OF THE AUTHORS: Each author made significant individual contributions to this manuscript. JAM was the main contributor to the elaboration of the manuscript. AAAJ conducted the review and led the discussion. JSSS worked on patient acquisition and clinical evaluation. CMO reviewed the final version of the article.

\section{REFERENCES}

1. Ivins GK. Meralgia Paresthetica, The Elusive Diagnosis Clinical Experience With 14 Adult Patients. Ann Surg. 2000;232(2):281-6.

2. Williams PH, Trzil KP. Management of meralgia paresthetica. J Neurosurg. 1991;74(1):76-80

3. Cho KT, Lee HJ. Prone Position-Related Meralgia Paresthetica after Lumbar Spinal Surgery: A Case Report and Review of the Literature. J Korean Neurosurg Soc. 2008;44(6):392-5

4. Gupta A, Muzumdar D, Ramani PS. Meralgia paraesthetica following lumbar spine surgery: a study in 110 consecutive surgically treated cases. Neurol India. 2004;52(1):64-6.
5. Mirovsky $Y$, Neuwirth M. Injuries to the lateral femoral cutaneous nerve during spine surgery. Spine (Phila Pa 1976). 2000;25(10):1266-9.

6. Mackinnon SE. Meralgia Paresthetica. In: Nerve Surgery. Mackinnon SE, editor. New York: Thieme Medical Publishers;2015.

7. Yang SH, Wu CC, Chen PQ. Postoperative meralgia paresthetica after posterior spine surgery: incidence, risk factors, and clinical outcomes. Spine (Phila Pa 1976). 2005;30(18):E547-50 